\title{
EFFECT OF SALICYLATES ON THE CIRCULATING EOSINOPHILS AND URINARY 17-KETOSTEROIDS IN MAN
}

BY

\author{
CHESTER B. THRIFT AND EUGENE F. TRAUT \\ From the Arthritis Clinic of Cook County Hospital, Chicago, the University of Illinois College of Medicine, and the \\ Presbyterian Hospital of Chicago, U.S.A.
}

The anti-inflammatory and analgesic effects of salicylates have been observed for centuries, but their mode of action remains obscure. Their recommendation as the cheapest and often the safest medicament in rheumatoid arthritis (Ragan, 1949) and in rheumatic fever (McEwen, 1954; Coburn, 1943) has led to renewed efforts to discover how they work.

Salicylates and cortisone may act similarly in stimulating the pituitary to produce adrenocorticotropin, and subsequently in stimulating the adrenal cortex to increase its production of cortisone. Salicylates act like cortisone in some respects, but are totally unlike it in many effects (Hailman, 1952). The evidence for and against stimulation of the hypothalamus or the anterior pituitary by salicylate to produce an ACTH-like effect is conflicting and fragmentary (Smith, Gray, and Lunnon, 1954a, b; Bayliss and Steinbeck, 1953, 1954a, b; Meade and Smith, 1951; Shuman and Finestone, 1950; Feeney, Carló, and Smith, 1955; Done and Kelley, 1956; Marson, 1953; Cronheim, King, and Hyder, 1952, 1953; Cronheim and Hyder, 1954; Roskam and van Cauwenberge, 1951; Hetzel and Hine, 1951). The earlier studies suggested a salicylate effect via the pituitary-adrenal axis, but later reports discount this idea, since salicylates are able to exert their effect in the adrenalectomized animal (Ingle, 1941).

Two tests according evidence of anterior pituitary and, subsequently, adrenal cortex activation are in common use. Adrenocorticotropic hormone in adequate doses indirectly and cortisone directly decrease the circulating eosinophils of the peripheral blood, while increasing the urinary excretion of ketosteroids. Most authorities approve of eosinopenia (the Thorn test) as a criterion of adrenal cortical stimulation (Thorn, Forsham, Prunty, and Hills, 1948; Shands and Bartter, 1952; Best, Kark, and Muehrcke, 1953).
Effect on Eosinophils.-A minimal depression of the circulating eosinophils (50-60 per cent.) is usually held to be necessary to establish a positive Thorn test. A distinction between the reaction of rheumatic and non-rheumatic individuals as regards eosinophil response and corticosteroid excretion has not been reported or, at least, the idea has not been accepted.

The published reports lack unanimity in describing the effect of salicylate upon the circulating eosinophils. Early studies indicated an eosinopenia following salicylate administration (Shuman and Finestone, 1950; Roskam and van Cauwenberge, 1951; Bertolani, Lorenzini, and Bonati, 1951), but recent workers have not confirmed this reported depression of the eosinophil count (McEwen, 1954; Meade and Smith, 1951; Marson, 1953; O'Connell, Roy, and Massell, 1955). It is suggested that the earlier results were due to the use of too large (i.e. toxic) doses of salicylate, so inducing a stress reaction (McEwen, 1954). According to Roskam and van Cauwenberge (1951), salicylates caused the eosinophils to decrease by 50 per cent. in 6 hours in rats. O'Connell and others (1955) found a salicylate potentiation of the eosinopenic effect of ACTH in humans; this was not interpreted as an effect upon the pituitary gland, but rather as a possible increase in peripheral utilization of the ACTH which was being given at the same time. Meade and Smith (1951) found that therapeutic doses produced no significant eosinopenia in 4 hours in humans. Lichtwitz (1944) again emphasized the distinction between the effects of therapeutic and toxic doses of salicylate in animal experiments.

Withdrawal Phenomena.-After withdrawal of steroids, the continuation by salicylate of the effects produced by doses of cortisone and adrenocorticotropin suggested that these drugs acted in a similar 
manner. On the other hand, the marked relapses and disturbances which followed the withdrawal of steroids did not follow the withdrawal of salicylate. Salicylates were also synergistic in reinforcing the beneficial action of corticosteroids and ACTH in rheumatic fever (McEwen, 1954; Fischel, Frank, and McEwen, 1955; Fischel, Frank, and Ragan, 1952).

Urinary 17-Ketosteroids.-Evidence for increased 17-corticosteroid excretion following the administration of salicylate has been similarly conflicting. Steroids do bring about an increase in 17-ketosteroid excretion. Van Cauwenberge and Heusghem (1951) found that salicylate therapy regularly caused a rise in urinary adrenal corticosteroids, and said that it was apparent that each increase in the excretion of the reducing steroids corresponded with clinical improvement; temperature, erythrocyte sedimentation rate, and subjective symptoms all improved simultaneously. This suggests a similarity between the results of salicylate and cortisone therapy. At least three other groups of investigators, however, found that salicylate had no influence on the urinary excretion of adrenocortical steroids (Smith and others, 1954a ; Bayliss and Steinbeck, 1954; Done and Kelley, 1956), and correspondingly, Norymberski, Stubbs, and West (1953) found no increase in the urinary ketosteroids. The explanation for the discrepancy in the findings has been the same: therapeutic doses do not raise the level of the 17-corticosteroids in the blood or urine, and toxic (too large) doses induce a non-specific stress effect.

Cushing's Syndrome.-Considering the frequency of Cushing's syndrome in patients treated with cortisone, Cochran, Watson, and Reid (1950) reported the development of a Cushing syndrome in a rheumatic fever patient treated with aspirin.

Adrenal Ascorbic Acid and Cholesterol.-Reduction of the content of ascorbic acid and cholesterol of the adrenal cortex is generally assumed to denote adrenal cortical activity mediated by ACTH (Feeney and others, 1955; Sayers, Sayers, Fry, White, and Long, 1944; Cronheim, King, and Hyder, 1952, 1953; Sayers, Sayers, Lewis, and Long, 1944; Rich, Berthrong, and Bennett, 1950). ACTH, as well as salicylates, has been found to deplete the ascorbic acid and cholesterol content of the adrenal glands in rats (Feeney and others, 1955). Hypophysectomy was found to prevent salicylates from reducing the ascorbic acid and cholesterol content of animal adrenals (Feeney and others, 1955; Sayers, Sayers, Lewis, and Long, 1944). On the other hand, however, some workers do not regard the reduction of ascorbic acid or cholesterol in the adrenal cortex as specifically indicating adrenocorticoid stimulation.

Feeney and others (1955) proved that depletion of adrenal ascorbic acid and cholesterol are not criteria for the anti-rheumatic properties of a drug. The ascorbic acid depletion of the adrenal cortex has been attributed to the "stress" effect on the adrenal cortex (too large) doses of salicylates, rather than to a specific adrenocorticotropic action (Smith and others, 1954; Norymberski and others, 1953; Sayers and others, 1944; Vogt, 1950; Roskam, van Cauwenberge, Vivario, and Vliers, 1955).

Carbohydrate Metabolism.-Several investigators have reported conflicting effects of salicylates upon carbohydrate metabolism, most agreeing that they increased blood sugar and glycosuria. Cortisone causes an increase in liver glycogen (Feeney and others, 1955; Ingle, 1950), while salicylates cause a fall in liver glycogen and reduce glycosuria in diabetic rats (Ingle, 1950).

Peripheral Blood.-In contrast with salicylates, cortisone tends to increase the erythrocytes and haemoglobin of the peripheral blood. Both cortisone and salicylates protect arteries against damage in experimental arteritis (Rich and others, 1950).

Uricosuria, Hyaluronidase, and Erythrocyte Sedimentation Rate.-Steroids and salicylates both increase uricosuria, lower the erythrocyte sedimentation rate, and have an anti-hyaluronidase effect. The metabolic changes following the administration of ACTH have been well summarized by Thorn, Prunty, and Forsham (1947), and the comparison of the metabolic effects of ACTH with those of salicylates have been summarized by Hailman (1952). The effects of steroids and salicylates are compared and contrasted in Table I.

TABLE I

SIMILARITIES AND DISSIMILARITIES BETWEEN THE EFFECTS OF STEROIDS AND SALICYLATES

\begin{tabular}{|c|c|c|c|}
\hline Results & Effects on & Steroids & Salicylates \\
\hline Similar & $\begin{array}{l}\text { Adrenal ascorbic acid } \\
\text { Adrenal cholesterol } \\
\text { Total lymphocytes } \\
\text { Erythrocyte sedimenta- } \\
\quad \text { tion rate } \\
\text { Uricosuria } \\
\text { Total eosinophils }\end{array}$ & $\begin{array}{l}\text { Decreased } \\
\text { Decreased } \\
\text { Decreased } \\
\text { Decreased } \\
\text { Increased } \\
\text { Decreased }\end{array}$ & $\begin{array}{l}\text { Decreased } \\
\text { Decreased } \\
\text { Decreased } \\
\text { Decreased } \\
\text { Increased } \\
\text { Decreased or } \\
\text { unaffected }\end{array}$ \\
\hline Dissimilar & $\begin{array}{l}\text { Withdrawal phenomena } \\
\text { Haemoglobin } \\
\text { Erythrocytes } \\
\text { Urinary 17-ketosteroids } \\
\text { Liver glycogen } \\
\text { Hyaluronidase } \\
\text { Cushing's syndrome }\end{array}$ & $\begin{array}{l}\text { Present } \\
\text { Increased } \\
\text { Increased } \\
\text { Increased } \\
\text { Increased } \\
\text { Inhibited } \\
\text { Induced }\end{array}$ & $\begin{array}{l}\text { Absent } \\
\text { Unaffected } \\
\text { Unaffected } \\
\text { Reports con- } \\
\text { flict } \\
\text { Decreased } \\
\text { Usually un- } \\
\text { affected } \\
\text { Usually ab- } \\
\text { sent }\end{array}$ \\
\hline
\end{tabular}




\section{Present Investigation}

We have attempted to determine whether therapeutic doses of salicylates increase the production of adrenocorticotropin, directly stimulate the adrenal cortex, or have a cortisone-like action.

Preliminary Study.-This project has grown from a previous (unpublished) study carried out by Traut, Cech, and Stoker in 1946 of eight patients with severe (Grade III) rheumatoid arthritis in the West Suburban Hospital of Oak Park, in the Cook County Hospital, and in the Oak Forest Infirmary, Cook County, Illinois. In this study the eosinophils were counted before administering salicylates 1 or $2 \mathrm{~g}$. daily orally or 4 to $8 \mathrm{~g}$. daily intravenously, immediately after, 4 hours after, and daily for 7 days after salicylates were started. The peripheral eosinophils were also counted by the same group of workers in patients who had taken salicylates regularly for years. It appeared that salicylates, even in doses sufficiently large to produce tinnitus and nausea, did not depress the level of the circulating eosinophils in the majority of cases. The results are shown in Table II.

TABLE II

EFFECT OF SODIUM SALICYLATE ON CIRCULATING EOSINOPHILS IN EIGHT PATIENTS WITH RHEUMATOID ARTHRITIS

UnPublished Preliminary Study Carried out by Traut, AND STOKER IN 1948

\begin{tabular}{c|c|c|c|c}
\hline \multirow{2}{*}{$\begin{array}{c}\text { Case } \\
\text { No. }\end{array}$} & \multicolumn{2}{|c|}{ Salicylates } & \multicolumn{1}{|c}{ Circulating } & Eosinophils \\
\cline { 2 - 4 } & Dose (g./day) & Route & $\begin{array}{c}\text { Before } \\
\text { Treatment }\end{array}$ & $\begin{array}{c}\text { After } \\
\text { Seventh Day }\end{array}$ \\
\hline 1 & 3 & Oral & 62 & 76 \\
\hline 2 & 2 & Intravenous & 300 & 481 \\
\hline 3 & 2 & Oral & 219 & 306 \\
\hline 4 & 4 & Oral & 119 & 112 \\
\hline 5 & 1 & Intravenous & 136 & 162 \\
\hline 6 & 4 & Oral & 131 & 125 \\
\hline 7 & 4 & Oral & 100 & 88 \\
\hline 8 & 4 & Oral & 125 & 125 \\
\hline & 8 & Oral & 100 & 106 \\
\hline
\end{tabular}

Tests Employed.-In the present investigation we have employed Thorn's test (depression of the circulating eosinophils: Thorn and others, 1948) and have also measured the urinary 17-corticosteroids after single and repeated doses of salicylates. The eosinophils were counted by the method of Pilot (1950), and the urinary ketosteroids were measured by the method of Archibald (1954).

Material.-We studied 43 female patients in the Cook County Hospital of Chicago. Fifteen of these patients had rheumatic disease, and 28 were non-rheumatic chosen at random.
Method.-The circulating eosinophils were counted before the study began, and 25 units of adrenocorticotropic hormone were administered to determine the ability of these patients to react normally in producing corticosteroids with an oxygen atom on the 11 and 17 carbon positions (the so-called 11-oxysteroids and 17-oxysteroids). Acetyl-salicylic acid was then given orally to establish a therapeutic level. On the fourth day the circulating eosinophils were again measured, and the plasma salicylate level was determined in sixteen of the patients by the method of Brodie, Udenfriend, and Coburn (1944). On the eighth day of salicylate administration, the plasma salicylate level was measured in seventeen patients and the number of circulating eosinophils was determined in all the patients. The results in the 43 patients are shown in Table III (opposite).

Results.-In only four patients (7 per cent.) of the 43 tested (Nos. 11, 30, 33, 35 in Table III) did the circulating eosinophils decrease by 50 per cent. or more; one of these patients (No. 33 in Table III) had eosinophilia (amounting to 34 per cent. in the differential count) accompanying lymphogranuloma. In five patients (12 per cent.) the circulating eosinophils decreased by about 30 per cent. In 23 patients ( 54 per cent.) they decreased by less than 30 per cent. In eleven patients they were unaffected. These last plateau curves were obtained only in patients with rheumatoid arthritis (Table III).

In forty patients there was either an initial increase or a decrease after the third day of salicylates, theo tendency being for the count on the eighth day to approximate to the initial count.

In eight patients (Nos. 36-43 to Table III), the enumeration of the circulating eosinophils was supplemented by a 24-hr determination of the urinary 17-ketosteroids before and after the administration of salicylates. The ketosteroid excretion increased by a negligible amount after the administration of salicylates for eight days. This increased excretion was not significant.

Thus, the number of circulating eosinophils fluctuated unevenly, but did not predominantly decrease. Neither did the urinary 17-ketosteroid excretion change in a manner characteristic of stimulation of the adrenal cortex.

\section{Summary}

The number of circulating eosinophils was not usually significantly decreased (i.e., by as much as 50 or 60 per cent.) by giving salicylates in therapeutic doses, and in some cases it actually increased. Nor did salicylates in full therapeutic doses increase the urinary excretion of 17-ketosteroids.

The initial increase or decrease in the eosinophils was followed by a return to the original count at the end of 8 days. In three exceptional patients 
TABLE III

EFFECT OF SALICYLATE ON CIRCULATING EOSINOPHILS IN 43 PATIENTS, ON PLASMA SALICYLATE LEVELS IN 28 PATIENTS, AND ON URINARY EXCRETION OF 17-KETOSTEROIDS IN EIGHT PATIENTS

\begin{tabular}{|c|c|c|c|c|c|c|c|c|c|}
\hline \multirow{2}{*}{$\begin{array}{l}\text { Case } \\
\text { No. }\end{array}$} & \multirow{2}{*}{ Diagnosis } & \multirow{2}{*}{$\begin{array}{l}\text { Oral Salicylates } \\
\text { (g./day) }\end{array}$} & \multicolumn{3}{|c|}{ Circulating Eosinophils } & \multicolumn{2}{|c|}{$\begin{array}{l}\text { Plasma Salicylate } \\
\text { Level (Brodie) }\end{array}$} & \multicolumn{2}{|c|}{$\begin{array}{l}\text { Urinary 17-Ketosteroids* } \\
\text { (mg./100 ml.) }\end{array}$} \\
\hline & & & $\begin{array}{c}\text { Before } \\
\text { Treatment }\end{array}$ & $\begin{array}{l}\text { After } \\
\text { 4th Day }\end{array}$ & $\begin{array}{c}\text { After } \\
\text { 8th Day }\end{array}$ & $\begin{array}{l}\text { After } \\
48 \mathrm{hrs}\end{array}$ & $\begin{array}{l}\text { After } \\
96 \mathrm{hrs}\end{array}$ & $\begin{array}{c}\text { Before } \\
\text { Treatment }\end{array}$ & $\begin{array}{c}\text { After } \\
8 \text { Days }\end{array}$ \\
\hline 1 & & 4 & 170 & 120 & 180 & - & - & - & - \\
\hline 2 & & 6 & 110 & 160 & 100 & - & - & - & - \\
\hline 3 & & 5 & 190 & 110 & 180 & - & - & - & - \\
\hline 4 & & 5 & 175 & 190 & 265 & - & - & - & - \\
\hline 5 & & 5 & 190 & 230 & 300 & - & - & - & - \\
\hline 6 & & 5 & 200 & 120 & 180 & & - & - & - \\
\hline 7 & & 5 & 360 & 320 & 280 & & - & 一 & - \\
\hline 8 & Rheumatic Fever & 5 & 330 & 350 & 300 & - & - & - & - \\
\hline 9 & Rheumatic Fever & 5 & 300 & 225 & 200 & - & - & - & - \\
\hline 10 & & $5 \cdot 5$ & 130 & 410 & 220 & - & - & - & - \\
\hline 11 & & $5 \cdot 5$ & 220 & 100 & 190 & - & - & - & - \\
\hline 12 & & 6 & 120 & 210 & 120 & - & - & - & - \\
\hline 13 & Rheumatic Fever & 6 & 120 & 190 & 130 & - & - & - & - \\
\hline 14 & Rheumatic Fever & 6 & 200 & 110 & 195 & - & - & - & - \\
\hline 15 & & 6 & 75 & 185 & 160 & - & - & - & - \\
\hline 16 & $\begin{array}{l}\text { Lupus Erythematosus } \\
\text { with Rheumatoid } \\
\text { Arthritis }\end{array}$ & 6 & 150 & 170 & 120 & $28 \cdot 0$ & - & - & - \\
\hline 17 & & 6 & 230 & 180 & 150 & $28 \cdot 5$ & - & - & - \\
\hline 18 & & 5 & 180 & 135 & 275 & $11 \cdot 0$ & - & - & - \\
\hline 19 & & 5 & 210 & 175 & 150 & - & $41 \cdot 5$ & - & - \\
\hline 20 & Salicylism & 5 & 40 & 100 & 100 & - & $10 \cdot 0$ & - & - \\
\hline 21 & & 5 & 130 & 140 & 280 & - & $30 \cdot 5$ & - & - \\
\hline 22 & & 5 & 130 & 142 & 150 & - & $20 \cdot 5$ & - & - \\
\hline 23 & & 8 & 410 & 350 & 400 & $25 \cdot 0$ & $51 \cdot 0$ & - & - \\
\hline 24 & Degenerative Arthritis & 6 & 230 & 150 & 160 & $17 \cdot 5$ & $40 \cdot 0$ & - & - \\
\hline 25 & Rheumatoid Arthritis & 6 & 80 & 90 & 80 & $25 \cdot 0$ & $32 \cdot 0$ & - & - \\
\hline 26 & & 4 & 270 & 300 & 230 & $7 \cdot 0$ & $20 \cdot 0$ & - & - \\
\hline 27 & Pulmonary Fibrosis & 5 & 650 & 760 & 220 & $8 \cdot 0$ & $25 \cdot 5$ & - & - \\
\hline 28 & $\begin{array}{l}\text { Allergy, Obesity and } \\
\text { Hypertension }\end{array}$ & 5 & 640 & 440 & 410 & $14 \cdot 0$ & $16 \cdot 0$ & - & - \\
\hline 29 & $\begin{array}{c}\begin{array}{c}\text { Chronic } \\
\text { Fever }\end{array} \\
\end{array}$ & 5 & 250 & 200 & 130 & $6 \cdot 0$ & $13 \cdot 0$ & - & - \\
\hline 30 & Rheumatic Fever & 6 & 260 & 130 & 200 & $21 \cdot 5$ & $44 \cdot 0$ & 一 & - \\
\hline 31 & Rheumatic Fever & 6 & 200 & 110 & 100 & $21 \cdot 5$ & $30 \cdot 0$ & - & - \\
\hline 32 & Rheumatic Fever & 6 & 410 & 500 & 400 & $26 \cdot 0$ & $30 \cdot 0$ & - & - \\
\hline 33 & Lymphogranuloma & 6 & 1,730 & 800 & 660 & $27 \cdot 0$ & $30 \cdot 5$ & - & - \\
\hline 34 & Rheumatoid Arthritis & 6 & 150 & 190 & 150 & $8 \cdot 0$ & $33 \cdot 5$ & - & - \\
\hline 35 & $\begin{array}{l}\text { Suicide attempted with } \\
\text { Aspirin }\end{array}$ & $\begin{array}{c}54 \\
\text { (toxic) }\end{array}$ & 62 & 180 & 121 & $41 \cdot 5$ & $1 \cdot 0$ & - & - \\
\hline 36 & & $5 \cdot 3$ & 105 & 160 & 100 & $18 \cdot 0$ & $20 \cdot 0$ & $10 \cdot 7$ & $1 \cdot 0$ \\
\hline
\end{tabular}


TABLE III-continued

\begin{tabular}{|c|c|c|c|c|c|c|c|c|c|}
\hline \multirow{2}{*}{$\begin{array}{l}\text { Case } \\
\text { No. }\end{array}$} & \multirow{2}{*}{ Diagnosis } & \multirow{2}{*}{$\begin{array}{l}\text { Oral Salicylates } \\
\text { (g.)day) }\end{array}$} & \multicolumn{3}{|c|}{ Circulating Eosinophils } & \multicolumn{2}{|c|}{$\begin{array}{c}\text { Plasma Salicylate } \\
\text { Level (Brodie) }\end{array}$} & \multicolumn{2}{|c|}{$\begin{array}{l}\text { Urinary } 17-\text { Ketosterojds* } \\
\text { (mg./100 ml.) }\end{array}$} \\
\hline & & & $\begin{array}{c}\text { Before } \\
\text { Treatment }\end{array}$ & $\begin{array}{l}\text { After } \\
\text { 4th Day }\end{array}$ & $\begin{array}{l}\text { After } \\
\text { 8th Day }\end{array}$ & $\begin{array}{l}\text { After } \\
48 \text { hrs }\end{array}$ & $\begin{array}{l}\text { After } \\
96 \text { hrs }\end{array}$ & $\begin{array}{l}\text { Before } \\
\text { Treatment }\end{array}$ & $\begin{array}{l}\text { After } \\
8 \text { Days }\end{array}$ \\
\hline 37 & Lupus Erythematosus & $6 \cdot 0$ & 75 & 80 & 60 & $20 \cdot 0$ & $23 \cdot 0$ & $5 \cdot 4$ & $9 \cdot 7$ \\
\hline 38 & & $5 \cdot 3$ & 175 & 475 & 330 & $20 \cdot 5$ & $26 \cdot 0$ & $1 \cdot 6$ & $14 \cdot 6$ \\
\hline 39 & Rheumatoid Arthritis & $6 \cdot 6$ & 80 & 120 & 270 & $17 \cdot 0$ & $21 \cdot 5$ & $3 \cdot 0$ & $4 \cdot 3$ \\
\hline 40 & & $8 \cdot 0$ & 110 & 140 & 110 & $17 \cdot 0$ & $32 \cdot 5$ & $10 \cdot 7$ & $8 \cdot 8$ \\
\hline 41 & Degenerative Arthritis & $6 \cdot 0$ & 70 & 85 & 75 & $25 \cdot 0$ & $41 \cdot 5$ & $9 \cdot 5$ & $3 \cdot 8$ \\
\hline 42 & & $6 \cdot 0$ & 135 & 110 & 155 & $10 \cdot 0$ & $15 \cdot 5$ & $2 \cdot 9$ & $6 \cdot 6$ \\
\hline 43 & & $8 \cdot 0$ & 310 & 330 & 365 & $2 \cdot 5$ & $12 \cdot 5$ & $3 \cdot 7$ & $3 \cdot 3$ \\
\hline
\end{tabular}

* Normal value for urinary 17 -ketosteroids in women is 4.6 to $13.4 \mathrm{mg} . / 100 \mathrm{ml}$.

with an initial eosinophilia, the eosinophils decreased more than 50 per cent., but in the majority the response of the adrenal cortex to salicylates was slight.

One patient (Case 20 in Table III) showed symptoms of salicylism upon attaining a level of $10 \mathrm{mg}$. salicylate per $100 \mathrm{ml}$. plasma, and the eosinophil count in this patient actually rose during this episode.

In a programme of maximum salicylate administration, blood salicylate levels should be estimated frequently (Coburn, 1943). Mental disturbance, incontinence, tinnitus, headache, nausea, and vomiting should be given due importance.

The presumption of salicylate benefits mediated by the pituitary gland or adrenal cortex is not therefore acceptable in the light of our findings.

We should like to give credit to the following workers in this field of investigation: Dr. A. Dubin, Director of Biochemistry, Hektoen Institute and Cook County Hospital, Chicago (Brodie blood salicylate levels); Dr. D. MacFadyen, Director of Biochemistry, Presbyterian Hospital, Chicago (17-ketosteroid excretion determination by Dr. Hillyer's modification of the Archibald method); Dr. E. Chesrow, Director of Oak Forest Infirmary, Chicago.

\section{REFERENCES}

A rchibald, R. M. (1954). J. clin. Endocr. 14, 353.

Bayliss, R. I. S., and Steinbeck, A. W. (1953), Biochem. J., 54, 523. - (1954a). Lancet, 1, 1010.

(1954b). Brit. med. J., 1, 486.

Bertolani, F., Lorenzini, R., and Bonati, B. (1951). Lancet, 1, 54.

Best, W. R., Kark, R. M., and Muehrcke R. C. (1953). J. Amer. med. Ass., 151, 702 .

Brodie, B. B., Udenfriend, S., and Coburn, A. F. (1944). J. Pharmacol., 80, 114.

Coburn, A. F. (1943), Bull. Johns Hopk. Hosp., 73, 435.

Cochran, J. B., Watson, R. D., and Reid, J. (1950). Brit. med. J., 2,1411.

Cronheim, G., and Hyder, N. (1954). Proc. Soc. exp. Biol. (N.Y.), 86, 409 .

_- King, J. S., Jr., and Hyder, N. (1952). Ibid., 80, 51.

,, (1953). Ibid., 82, 109.

C. and Kelley, V. C. (1956). Ann. rheum. Dis., 15, 71. i14, 299 .
Fischel, E. E., Frank, C. W., and McEwen, C. (1955). Ann. rheum. Dis., 14, 100.

- and Ragan, C. (1952). Medicine (Baltimore), 31, 331.

Hailman, H. F. (1952). J. clin. Endocr., 12, 454.

Hetzel, B. S., and Hine, D. C. (1951). Lancet, 2, 94

Ingle, D. J.' (1941). Endocrinology, 29, 649.

(1950). Proc. Soc. exp. Biol.' (N.Y.), 75, 673.

Lichtwitz, L. (1944). "Pathology and Treatment of Rheumatic 음 Fever," p. 175. Grune and Stratton, New York.

McEwen, C. (1954). Amer. J. Med., 17, 794.

Marson, F. G. W. (1953). Ann. rheum. Dis., 12, 296

Meade, B. W., and Smith, M. J. H. (1951). Lancet, 1, 773.

Norymberski, J. K., Stubbs, R. D., and West, H. F. (1953). Itid., 1,1276 .

O'Connell, P. A., Roy, A., and Massell, B. F. (1955). Amer. J. med. Sci., 229, 150 .

Pilot, M. I. (1950). Amer. J. clin. Path., 20, 870.

Ragan, C. (1949). J. Amer. med. Ass., 141, 124.

Rich, A. R., Berthrong, M., and Bennett, I. L., Jr. (1950). Bu Johis. Hopk. Hosp., 87, 549.

Roskam, J., and Van Cauwenberge, A. (1951). Lancet, 2, 375. 1105 .

Sayers, G. Sayers, M. A. Fry, E. G., White, A., and Long, C. N. H. (1944). Yale J. Biol. Med., 16, 361.

, Lewis H. L and Long C. N. H. (1944), Proc Soc. exp. Biol. (N.Y.), 55, 238 .

Shands, H. C., and Bartter, F. C. (1952). J. clin. Endocr., 12, 178. Shuman, C. R., and Finestone, A. J. (1950). Proc. Soc. exp. Biol. $\left(N . Y_{\text {. }}\right), 73,248$.

Smith, M. J. H., Gray, C. H., and Lunnon, J. B. (1954a). Lancet, $1,1008$.

(1954b). J. Endocr., 10, XVII (Proc.)

Thorn, G W Forsham, P H. Prunty, F T G., and Hills, A G (1948). J. Amer. med. Ass., 137, 1005.

Prunty, F. T. G., and Forsham, P. H. (1947). "Metabolic Changes Following the Administration of Pituitary Adrenocorticotrophic Hormone (ACTH) in Man," Trans. Ass. Amer. Phys., 60, 143.

Van Cauwenberge, H., and Heusghem, C. (1951). Lancet, 1, 771.

Vogt, M. (1950). Brit. med. J., 2, 1242.

L'effet des salicylates sur les éosinophiles sanguins et les 17-cétostéroïdes urinaires chez l'homme RÉSUMÉ

Des salicylates, en doses thérapeutiques, ne provoquaient pas généralement de chute appréciable (c'est-àdire en dessous de 50 ou 60 pour cent) des éosinophiles $v$ sanguins et même, quelquefois, leur chiffre se trouvait $\mathrm{N}$ augmenté. En fortes doses thérapeutiques, les salicylates n'ont pas, non plus, fait augmenter l'excrétion urinaire des 17-cétostéroïdes.

L'augmentation ou la diminution du chiffre des éosinophiles ne durait que 8 jours. Chez trois malades exceptionnels avec une éosinophilie initiale, le chiffre des éosinophiles baissa en dessous de $50 \%$, mais dans la plupart des cas l'écorce surrénale ne réagissait que faiblement aux salicylates. 
Un malade (No. 20 dans la Table III) acusa des symptômes de salicylisme au moment d'atteindre le taux de $10 \mathrm{mg}$. de salicylate par 100 c.c. de plasma; au cours de cet épisode le chiffre d'éosinophiles augmenta.

Quand on administre des doses maxima de salicylates, il faut déterminer souvent leur taux sanguin (Coburn, 1943), et considérer l'importance des désordres mentaux incontinence, tintement d'oreilles, céphalée, nausée et vomissement.

A la lumière de nos résultats on ne peut donc pas accepter l'hypothèse selon laquelle les effets favorables des salicylates seraient transmis par l'hypophyse ou l'écorce surrénale.

El efecto de los salicilatos sobre los eosinófilos circulantes y los 17-cetoesteroides urinarios en el hombre

\section{Sumario}

Los salicilatos, en dosis terapéuticas, no provocaban generalmente bajas significativas (es decir debajo de un 50 o 60 por ciento) de eosinófilos circulantes y hasta, a veces, sus cifras se veían aumentadas. Con fuertes dosis terapéuticas los salicilatos tampoco hacían aumentar la excreción urinaria de los 17-cetoesteroides.

El aumento o la disminución de la tasa de eosinófilos no duraba más de 8 días. En tres enfermos excepcionales con una eosinofilia inicial, la cifra de los eosinófilos cayó debajo del $50 \%$, pero en la mayoría de los casos la respuesta de la corteza suprarrenal a los salicilatos fué débil.

Un enfermo (No. 20 en el Cuadro III) acusó síntomas de salicilismo al alcanzar la tasa de $10 \mathrm{mg}$. de salicilato por 100 c.c. de plasma; durante este episodio su eosinofilia se vió aumentada.

Al administrar dosis maximas de salicilatos, hay que determinar su tasa sanguínea a menudo (Coburn, 1943) y atribuir importancia debida a desórdenes mentales, incontinencia, tintineo, cefalalgia, náusea y vómitos.

A la luz de nuestros resultados no se puede aceptar la hipótesis según la cual los efectos favorables de los salicilatos se transmiten por medio de la glándula pituitaria o la corteza suprarrenal. 